\title{
Glycated haemoglobin measurements from UK Biobank are different to those in linked primary care records: implications for combining biochemistry data from research studies and routine clinical care
}

Authors: Katherine G Young, ${ }^{1 *}$ Timothy J McDonald ${ }^{1,2}$ and Beverley M Shields ${ }^{1}$

${ }^{1}$ Institute of Biomedical and Clinical Science, College of Medicine and Health, University of Exeter, Exeter, UK, ${ }^{2}$ Department of Clinical Biochemistry, Royal Devon and Exeter NHS Foundation Trust, Exeter, UK

*Corresponding Author: Level 3 RILD Building, RD\&E Wonford, Barrack Road, Exeter, Devon, EX2 5DW, UK. E-mail: k.young3@exeter.ac.uk

\begin{abstract}
Data linkage of cohort or RCT data with routinely collected data is becoming increasingly commonplace, and this often involves combining biomarker measurements from different sources. However, sources may have different biases due to differences in assay method and calibration. Combining these measurements, or diagnoses based on these measurements, is therefore not always valid. We highlight an example using glycated haemoglobin $\mathrm{A} 1 \mathrm{c}(\mathrm{HbA1c})$ test results from two different sources in UK Biobank data.
\end{abstract}

Word count: 649 
medRxiv preprint doi: https://doi.org/10.1101/2021.11.20.21266511; this version posted January 17, 2022. The copyright holder for this preprint (which was not certified by peer review) is the author/funder, who has granted medRxiv a license to display the preprint in perpetuity.

It is made available under a CC-BY-NC 4.0 International license .

Biochemical tests of the same individual carried out on different test platforms are often not comparable due to bias in assay method and calibration ${ }^{1,2}$. Combining measurements from different sources, or diagnoses based on these measurements, is therefore not always valid. We highlight an example using glycated haemoglobin $\mathrm{A} 1 \mathrm{c}(\mathrm{HbA1c})$ test results from two different sources in UK Biobank data: $\mathrm{HbA1c}$ measurements taken at baseline assessment using a single assay method (the Bio-Rad Variant II Turbo HPLC analyser ${ }^{3}$ ); and HbA1c measurements from linked UK primary care records, where assay method was dependent on which NHS laboratory the sample was processed in.

We identified UK Biobank participants with no pre-existing or previous diagnosis of diabetes mellitus (any type), with a primary care $\mathrm{HbA} 1 \mathrm{c}$ measurement $\leq 100$ days before or after baseline assessment ( $n=1,039$; a detailed method is provided in Supplementary Figure S1). In individuals without diabetes, $\mathrm{HbA1c}$ should be relatively stable within this short timeframe. We found that UK Biobank baseline measurements were on average lower than primary care measurements with a mean difference of $2 \mathrm{mmol} / \mathrm{mol}$ (Figure 1), regardless of whether the primary care measurement was taken before or after baseline assessment.

The difference in measurements from the two sources may be due to a number of factors. These include biological variation within an individual due to the time difference between the primary care measurement and baseline assessment (-100 to +100 days). However, there was not a significant association between this time difference and the difference in the measurement values (Pearson correlation coefficient $=-0.025, P=0.4$; see Supplementary Figure $\mathrm{S} 2$ ). The difference in $\mathrm{HbA} 1 \mathrm{c}$ values is therefore likely to be due to methodological differences. We consider the most probable contributors to be the use of different $\mathrm{HbA1c}$ analysers, and differences in sample storage (UK Biobank stored blood samples frozen for 4-10 years prior to analysing $\left.{ }^{4}\right)$. A brief discussion of these methodological differences and their potential contributions can be found in Supplementary Table S2. It should be noted that the UK Biobank and all NHS laboratories are registered with external quality assurance (EQA) schemes which verify the performance of $\mathrm{HbA1c}$ assays ${ }^{3}$, indicating that 
measurements from both sources meet the appropriate standards to be used for clinical decision making.

Small differences in measurements from different sources, which may not be clinically significant at an individual patient level, can result in large differences when used to define disease cases in a large cohort. Using HbA1c thresholds to identify cases of pre-diabetes (HbA1c 42.0-47.9 mmol/mol) and type 2 diabetes $(\mathrm{HbA} 1 \mathrm{c} \geq 48.0 \mathrm{mmol} / \mathrm{mol})$ in this dataset results in under-diagnosis of prediabetes and diabetes when using UK Biobank HbA1c measurements compared to primary care $\mathrm{HbA1c}$ measurements, due to the differences between these measurements (Figure 2).

Participants who enter UK Biobank with a clinical diagnosis of type 2 diabetes will most likely have received this in primary care on the basis of an $\mathrm{HbA} 1 \mathrm{c}$ measurement $\geq 48.0 \mathrm{mmol} / \mathrm{mol}$. Additional cases of diabetes identified by a UK Biobank $\mathrm{HbA} 1 \mathrm{c} \geq 48.0 \mathrm{mmol} / \mathrm{mol}$ as in (5) cannot be treated as equivalent, because of the apparent difference between UK Biobank HbA1c measurements and primary care measurements. Re-aligning UK Biobank measurements using the equation of the linear regression line shown in Figure 1 as per Cull et al. ${ }^{6}$ may improve the comparability of these measurements. However, caution should be exercised as the $n=1,039$ primary care measurements in Figure 1 represent a range of different analysers, and only a subset of those used throughout the NHS for diagnostic diabetes testing.

Combining biochemical data from research studies with data from routine clinical care is becoming increasingly commonplace, whether for prospective cohorts such as UK Biobank or for randomised controlled trial participants ${ }^{7}$. Care must be taken to ensure that such data are equivalent and that it is valid to combine them. This is of particular importance when biomarkers are used to determine disease states, as in the case of $\mathrm{HbA} 1 \mathrm{c}$. 


\section{Ethics approval}

UK Biobank received ethical approval from the North West Multi-centre Research Ethics Committee (REC reference: 11/NW/03820). All participants gave written informed consent.

\section{Author contributions}

BMS and KGY conceived the study. KGY conducted the data analysis. All authors offered advice on the study design, analysis and interpretation of the results. KGY wrote the first draft of the manuscript. All authors read, reviewed, revised and approved the final manuscript.

\section{Data availability statement}

UK Biobank data are available through a procedure described at http://www.ukbiobank.ac.uk/usingthe-resource/.

\section{Supplementary data}

Supplementary data are available at IJE online.

\section{Funding}

This research was supported by Research England's Expanding Excellence in England (E3) fund.

\section{Acknowledgments}

This research has been conducted using the UK Biobank resource under Application Number 9072.

\section{Conflict of Interest}

None declared. 
medRxiv preprint doi: https://doi.org/10.1101/2021.11.20.21266511; this version posted January 17, 2022. The copyright holder for this preprint (which was not certified by peer review) is the author/funder, who has granted medRxiv a license to display the preprint in perpetuity.

It is made available under a CC-BY-NC 4.0 International license .

\section{References}

1. The EurA1c Trial Group. EurA1c: The European HbA1c Trial to Investigate the Performance of HbA1c Assays in 2166 Laboratories across 17 Countries and 24 Manufacturers by Use of the IFCC Model for Quality Targets. Clinical Chemistry 2018; 64: 1183-92.

2. Wiedmeyer H-M, Polonsky KS, Myers GL, et al. International Comparison of C-Peptide Measurements. Clinical Chemistry 2007; 53: 784-7.

3. Tierney A, Fry D, Almond R, Gordon M, Moffat S. UK Biobank Biomarker Enhancement Project - Companion Document to Accompany HbA1c Biomarker Data V1.0. 2018.

https://biobank.ndph.ox.ac.uk/showcase/showcase/docs/serum hb1ac.pdf. (3 Aug 2021, date last accessed).

4. UK Biobank. Biomarker assay quality procedures: approaches used to minimise systematic and random errors (and the wider epidemiological implications) V1.2. 2019. https://biobank.ctsu.ox.ac.uk/crystal/crystal/docs/biomarker issues.pdf. (3 Aug 2021, date last accessed).

5. Tavaglione F, De Vincentis A, Jamialahmadi O, et al. Inborn and acquired risk factors for severe liver disease in Europeans with type 2 diabetes from the UK Biobank. JHEP Reports 2021; 3: 100262.

6. Cull CA, Manley SE, Stratton IM, et al. Approach to maintaining comparability of biochemical data during long-term clinical trials. Clinical Chemistry 1997; 43: 1913-8.

7. Mc Cord KA, Al-Shahi Salman R, Treweek S, et al. Routinely collected data for randomized trials: promises, barriers, and implications. Trials 2018; 19: 1-9. 
medRxiv preprint doi: https://doi.org/10.1101/2021.11.20.21266511; this version posted January 17, 2022. The copyright holder for this preprint (which was not certified by peer review) is the author/funder, who has granted medRxiv a license to display the preprint in perpetuity. It is made available under a CC-BY-NC 4.0 International license.

\section{Figure 1}

Scatter plot of $\mathrm{HbA1c}$ measurements taken at UK Biobank baseline assessment vs those in primary care taken $\leq 100$ days before or after baseline assessment for $n=1,039$ individuals with no diagnosis of diabetes. Inset shows $30-50 \mathrm{mmol} / \mathrm{mol}$ values in more detail. Solid line: linear regression (equation: $y=0.9696 x+3.3595$ ); dashed line: line of equality.

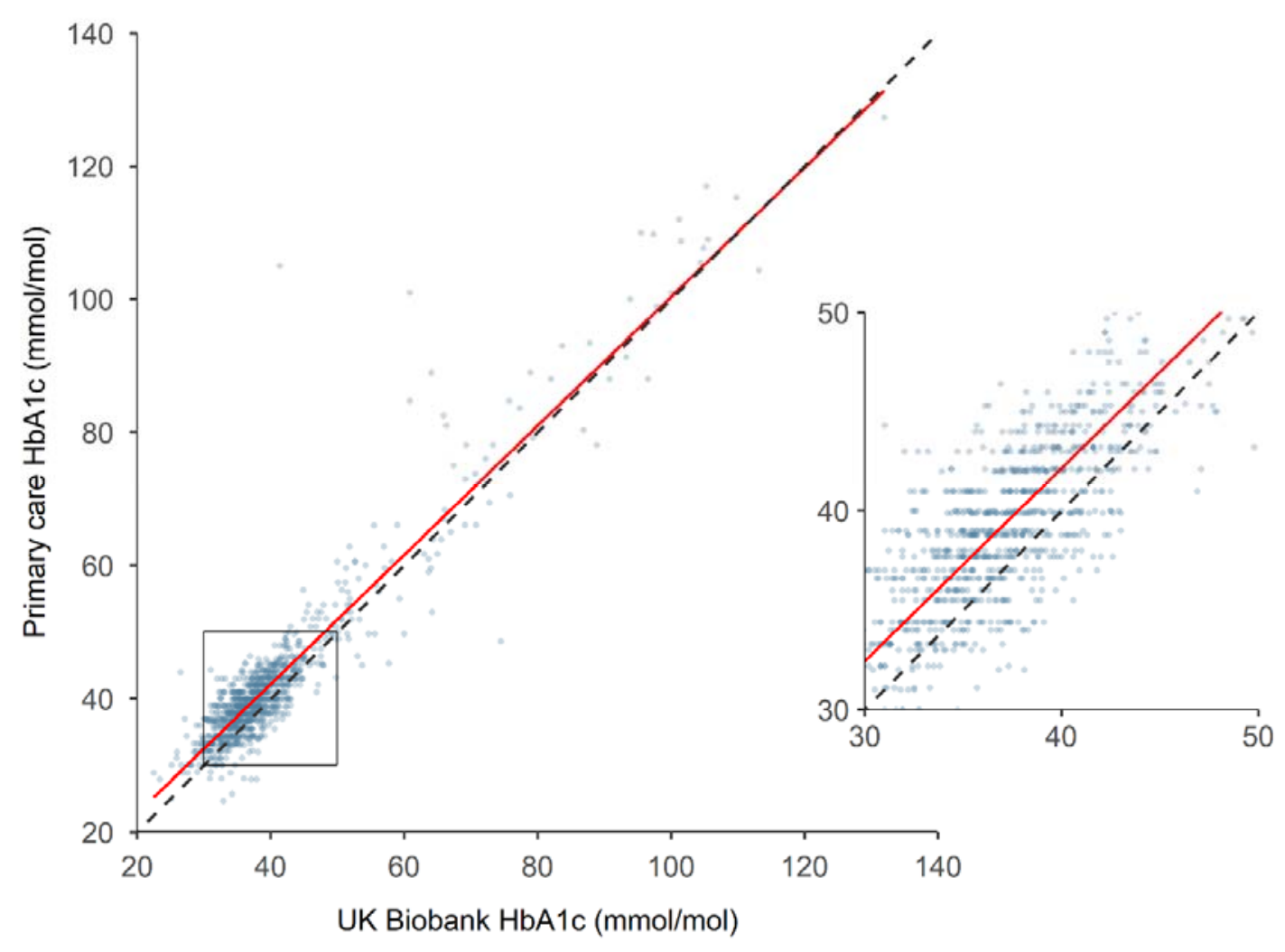


medRxiv preprint doi: https://doi.org/10.1101/2021.11.20.21266511; this version posted January 17, 2022. The copyright holder for this preprint (which was not certified by peer review) is the author/funder, who has granted medRxiv a license to display the preprint in perpetuity.

It is made available under a CC-BY-NC 4.0 International license .

\section{Figure 2}

Histogram of HbA1c measurements taken at UK Biobank baseline assessment and in primary care records taken $\leq 100$ days before or after baseline assessment for $n=1,039$ individuals with both measurements and no diagnosis of diabetes (x-axis truncated at $70 \mathrm{mmol} / \mathrm{mol}$ ). $\mathrm{HbA} 1 \mathrm{c}$ measurements in the 'normal' $(<42.0 \mathrm{mmol} / \mathrm{mol})$, pre-diabetes $(42.0-47.9 \mathrm{mmol} / \mathrm{mol})$, and diabetes $(\geq 48 / 0 \mathrm{mmol} / \mathrm{mol}$ ) ranges are indicated; counts for these categories are shown underneath.

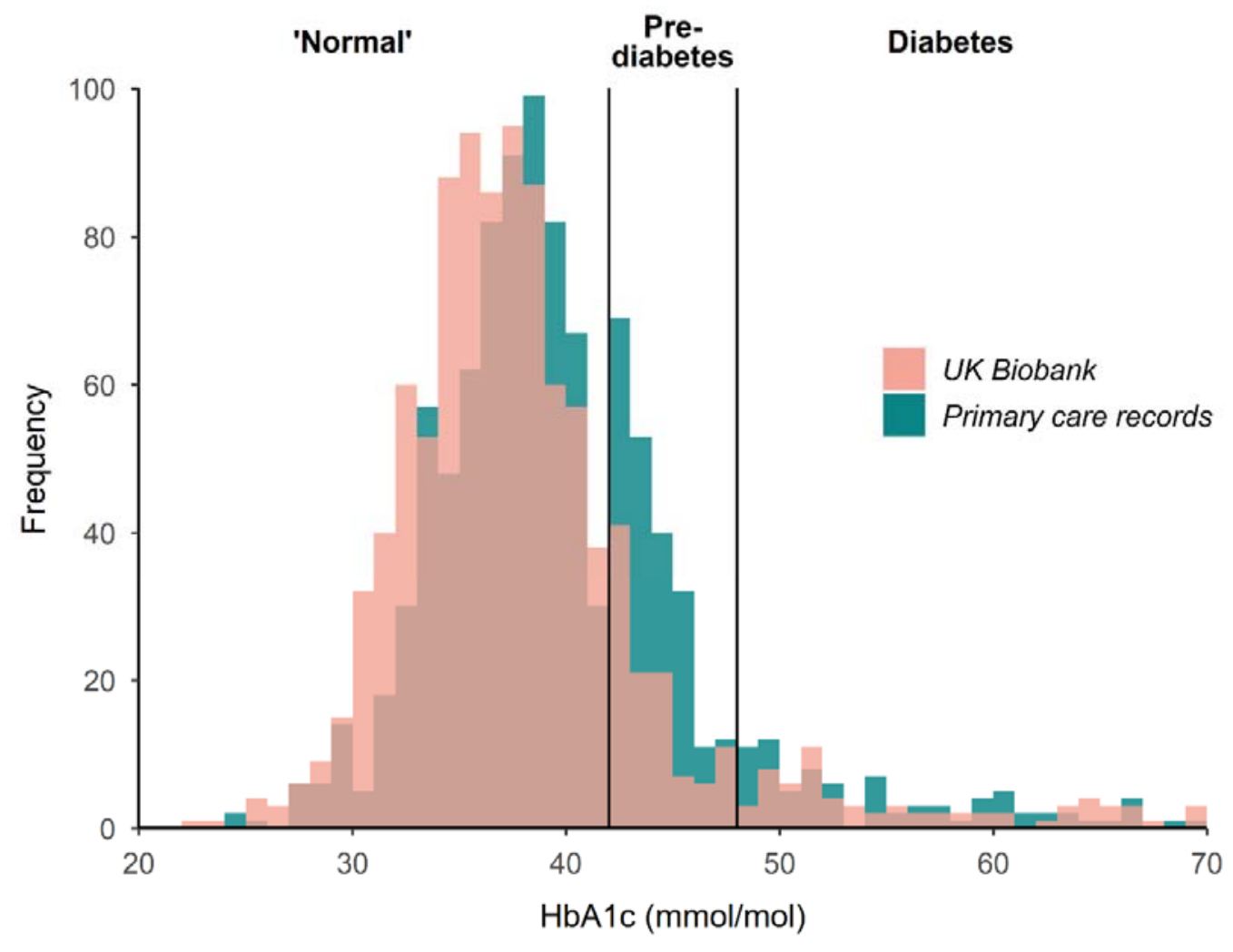

\begin{tabular}{r|c|c|c|}
\hline & $\begin{array}{c}\text { ‘Normal' (HbA1c } \\
<\mathbf{4 2 . 0} \mathbf{~ m m o l} / \mathbf{m o l})\end{array}$ & $\begin{array}{c}\text { Pre-diabetes (HbA1c } \\
\mathbf{4 2 . 0 - 4 7 . 9} \mathbf{~ m m o l} / \mathbf{m o l})\end{array}$ & $\begin{array}{c}\text { Diabetes (HbA1c } \\
>=\mathbf{4 8 . 0} \mathbf{~ m m o l} / \mathbf{m o l})\end{array}$ \\
\hline UK Biobank & $824(\mathbf{7 9} \%)$ & $112(11 \%)$ & $103(10 \%)$ \\
\hline Primary care records & $670(64 \%)$ & $240(23 \%)$ & $129(12 \%)$ \\
\hline
\end{tabular}

